8. Mylotte JM, White DW, McDermott C, Hodan C. Nosocomial bloodstream infection at a Veterans Hospital: 1979-1987. Infect Control Hosp Epidemiol 1989;10:455-464.

9. Stamm AM, Long MN, Belcher B. Higher overall nosocomial infection rate because of increased attack rate of methicillinresistant Staphylococcus aureus. Am J Infect Control 1993;21:7074.

10. Mylotte JM, Katuza J, Bentley DW. Methicillin-resistant Staphy- lococcus aureus: a questionnaire survey of 75 long-term care facilities in western New York. Infect Control Hosp Epidemiol 1992;13:711-718.

11. Lynch P, Jackson MM, Cummings MJ, Stamm WE. Rethinking the role of isolation practices in the prevention of nosocomial infections. Ann Intern Med 1987;107:243-246.

\title{
DOT Extends Compliance Date Again for Medical Waste Regulations
}

\section{by Gina Pugliese, RN, MS Medical News Editor}

In a Federal Register notice published on December 20, 1993, the Department of Transportation's (DOT) Research and Special Programs Administration has further extended the compliance date for regulations concerning transportation of infectious substances and regulated medical waste. The new compliance date is October 1 , 1994. The regulations originally were published December 21, 1990 , and materially changed in revisions issued December 20, 1991. In its petition for reconsideration, filed January 17, 1992, the American Hospital Association questioned the provisions' application to medical waste, called for interagency coordination, and urged the DOT to issue any changes in proposed form with an opportunity for public comment. The agency reportedly will issue a notice of proposed rulemaking some time in 1994, although no publication schedule has been announced. 